\title{
AGE AND GROWTH OF CAPOETA PESTAI (ACTINOPTERYGII: CYPRINIFORMES: CYPRINIDAE) IN A SMALL RIVER ENTERING LAKE EĞIRDIR, TURKEY
}

\author{
Yılmaz EMRE ${ }^{1,2}$, Aytac ALTIN ${ }^{3}$, Hakan AYYILDIZ ${ }^{3 *}$, Burak DÖLCÜ ${ }^{4}$, Fahrettin KÜÇÜK ${ }^{5}$, \\ and Özcan ÖZEN ${ }^{6}$ \\ ${ }^{1}$ Mediterranean Fisheries Research, Production and Training Institute, Kepez, Antalya, Turkey \\ ${ }^{2}$ Akdeniz University, Faculty of Sciences, Department of Biology, Antalya, Turkey \\ ${ }^{3}$ Canakkale Onsekiz Mart University, Gokceada School of Applied Sciences, Department of Fisheries Technology, \\ Gökçeada, Çanakkale, Turkey \\ ${ }^{4}$ Fisheries Research Station, Egirdir, Isparta, Turkey \\ ${ }^{5}$ Suleyman Demirel University, Faculty of Fisheries, Egirdir, Isparta, Turkey \\ ${ }^{6}$ Canakkale Onsekiz Mart University, Faculty of Marine Sciences and Technology, Canakkale, Turkey
}

Emre Y., Altın A., Ayyıldız H., Dölcü B., Küçük F., Özen Ö. 2016. Age and growth of Capoeta pestai (Actinopterygii: Cypriniformes: Cyprinidae) in a small river entering Lake Eğirdir, Turkey. Acta Ichthyol. Piscat. 46 (2): 57-63.

Background. Capoeta pestai (Pietschmann, 1933) is commercially important fish species in Turkey. The knowledge of the biology of this species is very scarce. This species has a 'critically endangered' status on the IUCN Red List. The objective of this study was to determine the age and growth rates of C. pestai, and to evaluate whether otolith morphometrics could be used as an age predictor.

Material and methods. Fish were collected from a small river entering Lake Eğirdir between January and December 2012. Fish samples were obtained from shallow parts of the river $(30-40 \mathrm{~cm}$ depth) seasonally in a single station by using an electrofishing devise.

Results. Annual growth increments were counted on the otoliths of 154 specimens, ranging from 6.2 to $26.8 \mathrm{~cm}$ total lengths. Estimated ages ranged from $0+$ to $7+$ years old. The von Bertalanffy growth curve was fitted to the age/total length data as follows: $L_{\infty}=47.83 \mathrm{~cm}$ (TL), $K=0.081, t_{0}=-1.840$, for females; $L_{\infty}=41.25 \mathrm{~cm}(\mathrm{TL})$, $K=0.086, t_{0}=-1.99$ for males; $L_{\infty}=52.45 \mathrm{~cm}(\mathrm{TL}), K=0.067, t_{0}=-1.84$ for all specimens. No significant differences in morphometric measures (length, width, and mass) were found between left and right otoliths (paired $t$-test, $P>0.05$ ). Otolith length and width showed significant linear relations with the total length while otolith mass represented by power model.

Conclusion. This study provides the first information on age, growth and otolith morphometric parameters of $C$. pestai. In addition, otolith morphometric measurements could possibly be used in future as an age predictor for C. pestai.

Keywords: age, growth, asteriscus, otolith morphometry, Capoeta pestai, age prediction, growth rings, population parameters

\section{INTRODUCTION}

Fishes of the genus Capoeta Valenciennes, 1842 are widely distributed in western Asia (Bănărescu 1999, Türkmen et al. 2002). Capoeta pestai (Pietschmann, 1933), which is commercially captured, is found in Turkey in Lake Eğirdir (Freyhof 2014), Beyșehir Lake, very rarely with Çarsamba Canal, Sarı̈z and Bakaran streams (Küçük et al. 2007) and in the Uçpınar Stream (Turan 2008). This species is mostly a lacustrine species, but also inhabits wetlands and freshwater streams (Özcan and Turan 2009). Capoeta pestai is on IUCN Red List (Freyhof 2014) as it is critically endangered (Freyhof 2014).

Age determination of fish is commonly based on counts of otolith growth rings. It is often a time-consuming and labour-intensive task (Francis and Campana 2004, Fey and Linkowski 2006). Reliable age estimates are

\footnotetext{
* Correspondence: Dr Hakan Ayyıldız, Gökçeada Uygulamalı Bilimler Yüksekokulu, Balıkçılık Teknolojisi Bölümü, 17760, Gökçeada, Çanakkale, Turkey, phone: +9028688723 02, fax: +902868872303, e-mail: (YE) yemre57@yahoo.com, (AA) aytacaltin@gmail.com, (HA) h ayyildiz17@hotmail.com, (BD)burak.dolcu@gthb.gov.tr, (FK)fahrettinkucuk@sdu.edu.tr, (OO)oozen@yahoo.com.
} 
especially difficult for long-lived species because of the slow growth and narrow increments in the older growth rings (Stransky et al. 2005). Moreover, accurate otolith ageing requires much practice. Therefore, many studies have used alternative methods for ageing such as the relations between fish size or otolith morphometric measurements and age (Francis and Campana 2004, Fey and Linkowski 2006, Steward et al. 2009, Javor et al. 2011, Matić-Skoko et al. 2011, Škeljo et al. 2012). Age and growth studies have been carried out on different Capoeta species (Türkmen et al. 2002, Alp et al. 2005, Kalkan 2008, Sen et al. 2008, Calta et al. 2010, Çoban et al. 2013, Ayyildiz et al. 2014, Emre et al. 2014, Innal 2014), however no studies have been conducted related to population dynamics for Capoeta pestai.

Therefore, the main goal of this study was to determine the age and growth rates of $C$. pestai, and to evaluate whether otolith morphometrics could be used as an age predictor.

\section{MATERIALS AND METHODS}

Sampling. Fish collection was carried out from a small river entering Lake Eğirdir, located at $38^{\circ} 03^{\prime} 24^{\prime \prime} \mathrm{N}, 30^{\circ} 51^{\prime} 58^{\prime \prime} \mathrm{E}$, nearly $917 \mathrm{~m}$ altitude (above sea level) in the Turkish Lakes Region and is $186 \mathrm{~km}$ north of Antalya. The bottom of the sampling site was commonly rocky with pebbles and the water was generally clear with slow running. Fish samples were obtained from shallow parts of the river (30-40 cm depth) seasonally in a single station by using an electro shocker (Honda EU20i, 220W 12V 8A) between January and December 2012. The electrodes were fitted with two wooden spreaders in order to keep them parallel at a distance of $50-60 \mathrm{~cm}$.

Length-weight relation. Total length (TL) of specimens was measured to the nearest $0.1 \mathrm{~cm}$ and the fish were weighed to the nearest $0.01 \mathrm{~g}$. Sex determination was performed by direct observation of gonads. The sex ratio (number of males to each female; $M: F$ ) of the samples was analysed. The Mann-Whitney $U$ test was applied to test the existence of significant differences between sexes according to the total length. The relation between the total length and the total weight was calculated for each sex separately using a power function:

$$
W=a \mathrm{TL}^{b}
$$

where: $b$ is the regression coefficient and $a$ is the regression constant. The regression parameters $a, b$, and the coefficient of determination $\left(r^{2}\right)$ were estimated for all individuals and for each sex with log-transformed data by linear regressions. The allometric index value $(b)$ was compared to the theoretical value of 3 by a $t$-test (Zar 1984). Analyses of covariance (ANCOVA) were applied to determine any significant differences in the linear relations between sexes.

Age and growth. The lagenar otolith (asteriscus) pairs were removed, cleaned, dried, and stored in plastic vials. From each pair, one otolith was randomly selected and immersed in plastic vial with glycerine solution for a week. Counts of rings in each otolith were read blind by experienced reader, without knowing the fish length or the date of capture. All otoliths were read twice and final age estimates achieved when the same results were obtained from the two readings. A stereomicroscope with objective lenses with nominal magnifications ranging from $\times 0.5$ to $\times 5.6$ was used for the counts.

Ages were determined by counting the number of opaque and translucent rings from the nucleus to the outer edge of the otolith (Fig. 1). The von Bertalanffy growth curve was fitted to the length at age data using non-linear least squares parameter estimation (von Bertalanffy 1938):

$$
T L=L_{\infty}\left[1-e^{-K\left(t-t_{0}\right)}\right]
$$

where TL is the fish length at age $t$ (year), $L_{\infty}$ the theoretical asymptotic length, $K$ the growth rate coefficient, and $t_{0}$ the theoretical age when fish length is zero. Separate analyses were carried out for males, females and all specimens.

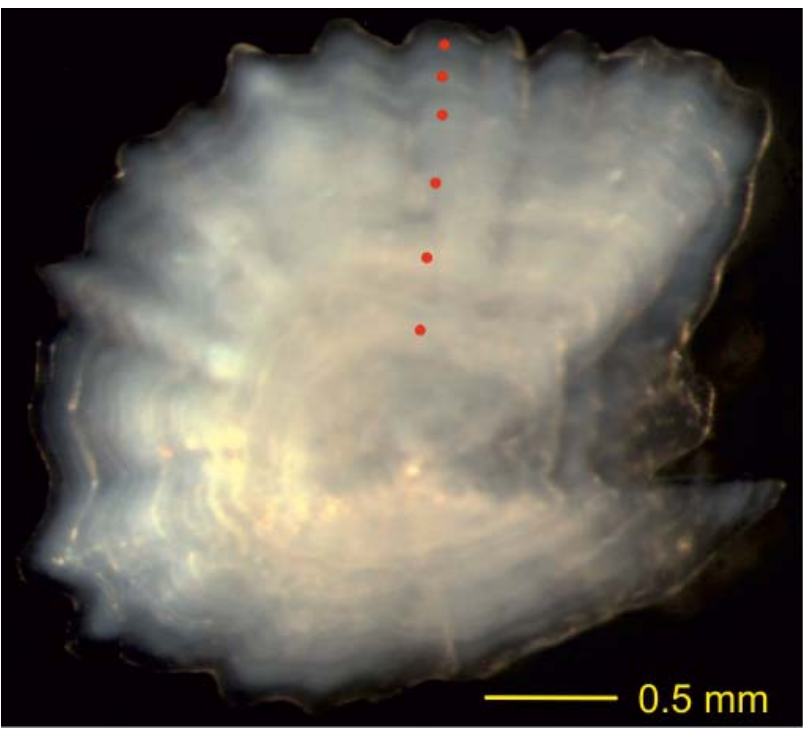

Fig. 1. Asteriscus otolith of Capoeta pestai ( $W=107.4 \mathrm{~g}$, $\mathrm{TL}=23.5 \mathrm{~cm}$, age $6+$, November 2012)

Otolith morphometrics. Otolith length (OL) and width (OW) were measured to the nearest $0.01 \mathrm{~mm}$ using $\mathrm{Q}$ Capture Imaging Software and weighed (OM) to the nearest $0.00001 \mathrm{~g}$ using a Shimadzu electronic balance. $\mathrm{OL}$ was defined as the longest axis between the anterior and posterior otolith edge and OW as a distance from the dorsal to the ventral edge. Differences between left and right otoliths were tested by paired $t$-test. The relation between the somatic growth and the otolith growth was investigated by linear regression. Relations between age and otolith weight were calculated using the power model.

\section{RESULTS}

Length-weight relation. A total of 154 individuals were collected; 44 (28.5\%) were females, 104 (67.5\%) males and $6(4 \%)$ individuals undetermined sex. Female and male total lengths ranged from 9.8 to $26.8 \mathrm{~cm}$ and from 6.2 to $22.0 \mathrm{~cm}$, respectively (Fig. 2). A higher proportion of males were observed in the $\leq 20.0 \mathrm{~cm}$ length classes 
while females were more abundant in the $\geq 20.0 \mathrm{~cm}$ length classes. Also, only females were sampled in the larger than $22 \mathrm{~cm}$ length classes. The overall male : female ratio $(M$ : $F=2.36: 1.00)$ was biased in favour of males. The MannWhitney $U$ test revealed significant differences between sexes, regarding TL $(U=940, z=-5.654 ; P<0.05)$.

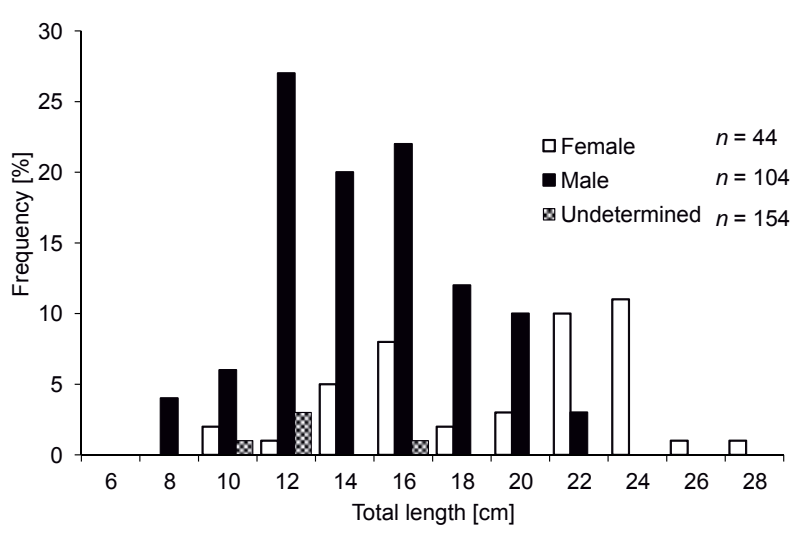

Fig. 2. Length-frequency distribution of males, females and all Capoeta pestai specimens collected in a small river entering Lake Eğirdir, during the sampling period

The parameters of the length-weight relations are provided for each sex and all individuals in Table 1. Our data suggested that Capoeta pestai showed positive allometric growth. The parameter $b$ of length-weight relations was significantly different from $3(P<0.05)$. The ANCOVA test indicated that length-weight relations were not significantly different in slopes or intercept between the two sexes (ANCOVA, $n=154 ; P>0.05$ ).

Table 1

Parameters of the length-weight relations for males, females and all individuals (males, females, immature) of Capoeta pestai in a small river entering Lake Eğirdir

\begin{tabular}{lrcccc}
\hline & $\mathrm{N}$ & $\mathrm{a}$ & $\mathrm{b}$ & $R^{2}$ & $P$ \\
\hline Males & 104 & 0.0053 & 3.183 & 0.985 & $<0.01$ \\
Females & 44 & 0.0070 & 3.073 & 0.984 & $<0.01$ \\
All individuals & 154 & 0.0063 & 3.117 & 0.986 & $<0.01$ \\
\hline
\end{tabular}

Age and growth. Based on the annual growth ring counts of $154 C$. pestai asteriscus otoliths, age classes ranged between $0+$ and $7+$ years (Table 2 ). Most of the fish, accounting for $61.7 \%$ of the total sample, were between $2+$ and $4+$ years old. Fish younger than $1+$ year old and older than $6+$ years old were poorly represented in the sample (Fig. 3). Males were dominant in the younger age groups $(1+, 2+, 3+$, and $4+)$, while the females were abundant in age classes $5+$ and $6+$. Moreover, age classes of $7+$ years represented by only females.

The von Bertalanffy growth curves for total lengths at age of females, males and all specimens are shown in Fig. 4. The estimated parameters of the equation were: $L_{\infty}=47.83 \mathrm{~cm}(\mathrm{TL}), K=0.081, t_{0}=-1.840$, for females;
$L_{\infty}=41.25 \mathrm{~cm}$ (TL), $K=0.086, t_{0}=-1.99$ for males; $L_{\infty}=52.45 \mathrm{~cm}(\mathrm{TL}), K=0.067, t_{0}=-1.84$ for all specimens.

Table 2

Age-length key for Capoeta pestai from Lake Eğirdir, Turkey

\begin{tabular}{lrrrrrrrr}
\hline $\begin{array}{c}\text { Total } \\
\text { length } \\
{[\mathrm{cm}]}\end{array}$ & \multicolumn{8}{c}{ Age class } \\
\cline { 2 - 9 } & $0+$ & $1+$ & $2+$ & $3+$ & $4+$ & $5+$ & $6+$ & $7+$ \\
\hline $6-7.9$ & 3 & 1 & & & & & & \\
$8-9.9$ & & 6 & 1 & & & & & \\
$10-11.9$ & & 11 & 20 & 1 & & & & \\
$12-13.9$ & & & 14 & 12 & & & & \\
$14-15.9$ & & & & 24 & 8 & & & \\
$16-17.9$ & & & & 1 & 11 & 2 & & \\
$18-19.9$ & & & & & 3 & 6 & 3 & \\
$20-21.9$ & & & & & & 8 & 5 & \\
$22-23.9$ & & & & & & 3 & 5 & 4 \\
$24-25.9$ & & & & & & & & 1 \\
$26-27.9$ & & & & & & & & 1 \\
N & 3 & 18 & 35 & 38 & 22 & 19 & 13 & 6 \\
Mean TL & 6.5 & 9.9 & 11.6 & 14.3 & 16.5 & 19.9 & 21.5 & 24.5 \\
Mean $W$ & 1.96 & 7.80 & 13.52 & 27.32 & 41.10 & 68.61 & 92.13 & 127.16 \\
\hline
\end{tabular}

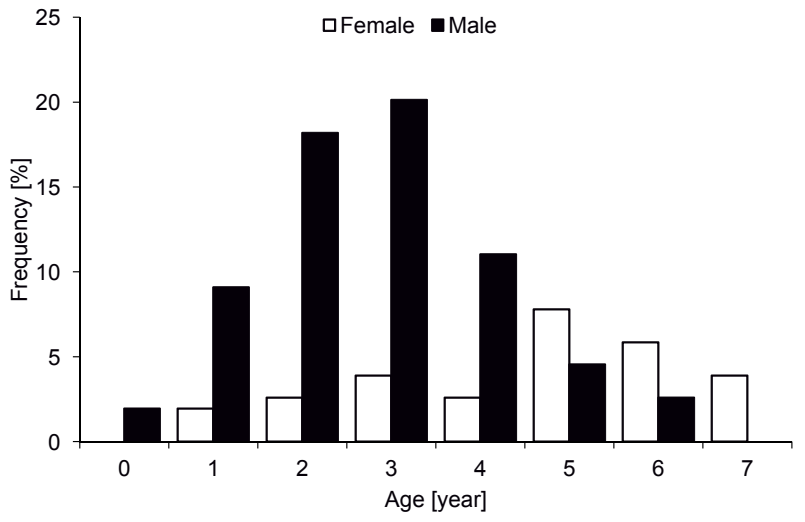

Fig. 3. Age structure of Capoeta pestai males, females and all specimens from a small river entering Lake Eğirdir

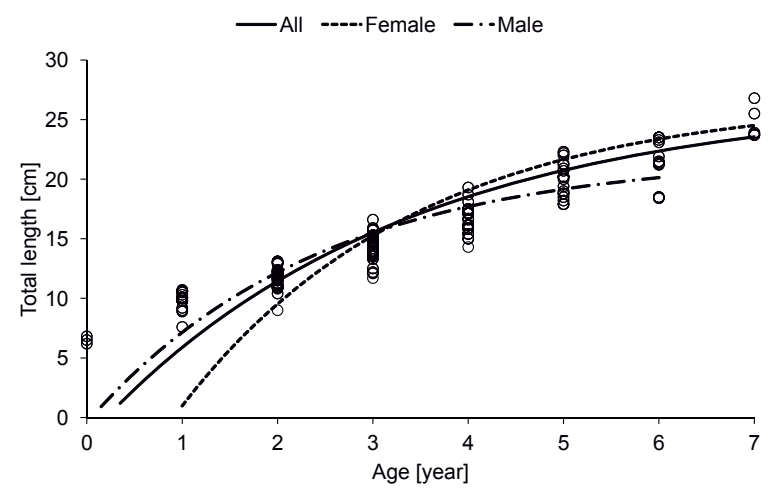

Fig. 4. The von Bertalanffy growth curves for Capoeta pestai specimens, from a small river entering Lake Eğirdir females, males and overall 
Table 3

Morphometric measurements of asteriscus otolith according to the age of Capoeta pestai from a small river entering Lake Eğirdir, Turkey

\begin{tabular}{|c|c|c|c|c|c|c|c|c|c|c|c|c|c|c|}
\hline \multirow{2}{*}{ Age } & \multirow{2}{*}{ Sex } & \multirow{2}{*}{$N$} & \multicolumn{4}{|c|}{ Otolith length [mm] } & \multicolumn{4}{|c|}{ Otolith width [mm] } & \multicolumn{4}{|c|}{ Otolith mass [g] } \\
\hline & & & Min. & Max. & Mean & SD & Min. & Max. & Mean & SD & Min. & Max. & Mean & SD \\
\hline \multirow[t]{2}{*}{$0+$} & Male & 3 & 1.16 & 1.24 & 1.20 & 0.04 & 0.89 & 0.96 & 0.92 & 0.04 & 0.00035 & 0.00042 & 0.00039 & 0.00004 \\
\hline & Female & 3 & 1.64 & 1.74 & 1.68 & 0.06 & 1.32 & 1.42 & 1.36 & 0.05 & 0.00091 & 0.00107 & 0.00098 & 0.00008 \\
\hline \multirow[t]{3}{*}{$1+$} & Male & 14 & 1.34 & 1.76 & 1.64 & 0.12 & 1.21 & 1.43 & 1.33 & 0.08 & 0.00054 & 0.00109 & 0.00092 & 0.00016 \\
\hline & All & 17 & 1.34 & 1.76 & 1.64 & 0.11 & 1.21 & 1.43 & 1.34 & 0.07 & 0.00054 & 0.00109 & 0.00093 & 0.00015 \\
\hline & Female & 4 & 1.96 & 2.18 & 2.08 & 0.10 & 1.61 & 1.75 & 1.69 & 0.07 & 0.00144 & 0.00170 & 0.00156 & 0.00012 \\
\hline \multirow[t]{3}{*}{$2+$} & Male & 28 & 1.71 & 2.06 & 1.88 & 0.10 & 1.44 & 1.72 & 1.55 & 0.08 & 0.00090 & 0.00164 & 0.00129 & 0.00017 \\
\hline & & 32 & 1.71 & 2.18 & 1.91 & 0.12 & 1.44 & 1.75 & 1.56 & 0.10 & 0.00090 & 0.00170 & 0.00132 & 0.00019 \\
\hline & Female & 6 & 2.24 & 2.5 & 2.36 & 0.15 & 1.35 & 2.13 & 1.85 & 0.26 & 0.00180 & 0.00210 & 0.00194 & 0.00015 \\
\hline \multirow[t]{3}{*}{$3+$} & Male & 31 & 1.96 & 2.89 & 2.30 & 0.22 & 1.26 & 2.68 & 1.93 & 0.24 & 0.00144 & 0.00310 & 0.00215 & 0.00043 \\
\hline & All & 37 & 1.96 & 2.89 & & 0.21 & 1.26 & 2.68 & 1.92 & 0.25 & 0.00144 & 0.00310 & 0.00211 & 0.00040 \\
\hline & Female & 4 & 2.27 & 2.78 & 2.49 & 0.21 & 1.99 & 2.19 & 2.06 & 0.09 & 0.00220 & 0.00320 & 0.00252 & 0.00047 \\
\hline \multirow[t]{3}{*}{$4+$} & Male & 17 & 2.40 & 3.17 & 2.62 & 0.20 & 2.05 & 2.52 & 2.18 & 0.11 & 0.00220 & 0.00360 & 0.00300 & 0.00042 \\
\hline & All & 21 & 2.27 & 3.17 & 2.59 & 0.20 & 1.99 & 2.52 & 2.16 & 0.12 & 0.00220 & 0.00360 & 0.00291 & 0.00046 \\
\hline & Female & 12 & 2.46 & 3.3 & & 0.24 & 2.20 & 2.83 & 2.56 & & 0.00290 & & 0.00413 & 0.00065 \\
\hline \multirow[t]{3}{*}{$5+$} & Male & 7 & 2.70 & 3.27 & 2.87 & 0.19 & 2.22 & 2.79 & 2.39 & 0.19 & 0.00330 & 0.00492 & 0.00362 & 0.00058 \\
\hline & All & 19 & 2.46 & 3.31 & & 0.22 & 2.20 & 2.83 & 2.50 & 0.20 & & & 0.00394 & 0.00066 \\
\hline & Female & 9 & 2.55 & 3.71 & 3.17 & 0.32 & 2.50 & 3.06 & 2.71 & 0.16 & 0.00340 & 0.00580 & 0.00500 & 0.00075 \\
\hline \multirow[t]{2}{*}{$6+$} & Male & 4 & 2.49 & 3.17 & 2.83 & 0.30 & 2.18 & 2.71 & 2.48 & 0.24 & 0.00360 & 0.00460 & 0.00403 & 0.00051 \\
\hline & All & 13 & 2.49 & 3.71 & 3.07 & 0.34 & 2.18 & 3.06 & 2.64 & 0.21 & 0.00340 & 0.00580 & 0.00470 & 0.00081 \\
\hline $7+$ & Female & 6 & 3.20 & 3.91 & 3.56 & 0.24 & 2.63 & 3.37 & 3.04 & 0.25 & 0.00480 & 0.00744 & 0.00605 & 0.00091 \\
\hline
\end{tabular}

$\mathrm{OL}=$ otolith length, $\mathrm{OW}=$ otolith width, $\mathrm{OM}=$ otolith mass.

Otolith morphometric measurements. Otolith morphometric measurements were done on 154 specimens. Their otolith length, width, and mass ranged within 1.16-3.91 mm, 0.89-3.37 mm, and 0.0003-0.0074 g, respectively (Table 3). Statistically no significant differences in morphometric measures (OL, OW, and $\mathrm{OM}$ ) were found between left and right otoliths (paired $t$-test, $P>0.05)$ or between the sexes $(P>0.05)$. OL and OW showed significant linear relations with the TL while OM represented by power model (Table 4).

The relations between otolith morphometric measurements and age were shown in Fig. 5. A power model explained between $82.11 \%$ and $87.72 \%$ of the variation in

\section{Table 4}

Parameters of the relation between the otolith measurements and the fish total length for Capoeta pestai from a small river entering Lake Eğirdir, Turkey

\begin{tabular}{lcccccc}
\hline $\begin{array}{c}\text { Otolith-fish } \\
\text { length } \\
\text { relations }\end{array}$ & Model & $n$ & $a$ & $b$ & $r^{2}$ & $\mathrm{P}$ \\
\hline OL-TL & Linear & 154 & 0.127 & 0.434 & 0.947 & $<0.01$ \\
OW-TL & Linear & 154 & 0.256 & 0.113 & 0.935 & $<0.01$ \\
OM-TL & Power & 154 & 0.0000077 & 2.088 & 0.982 & $<0.01$ \\
\hline
\end{tabular}

$n=$ number of specimens, $a=$ slope of the regression line, $b=\mathrm{y}$-intercept, $r^{2}=$ coefficient of determination; $\mathrm{TL}=$ fish total length, $\mathrm{OL}=$ otolith length, $\mathrm{OW}=$ otolith width, $\mathrm{OM}=$ otolith mass. age. Most precise age estimations were obtained from the OM data $\left(r^{2}\right)$ followed by the OW and OL (Table 5).

\section{DISCUSSION}

The analysis of covariance showed no significant difference between males and females in the lengthweight relation, although females tended to be slightly longer than males. The exponents of length-weight relation of the Capoeta pestai estimated in this study, shows a positive allometric growth $(b=3.117)$. This value is close to that obtained for the same species from the Melendiz Creek and Lake Eğirdir (Erk'akan et al. 2013, Ayyildiz et al. 2015).

The presently reported study provides the first information about age, growth rates, and the otolith morphometric measurements of Capoeta pestai by using asteriscus otolith. Asteriscus otoliths are useful structures for age estimation of C. pestai. The otoliths of C. pestai showed clearly identifiable opaque and translucent bands. Considering the otolith ring formations as annual, the maximum age of $C$. pestai were determined as $7+$. Males of the population were dominated by younger age classes, while the females were abundant in the older age classes. The findings of the current study are consistent with those of Türkmen et al. (2002) who found that males were dominated at younger age classes for Capoeta umbla (Heckel, 1843).

Growth parameters calculated in this study represent the first estimations of Capoeta pestai. Therefore, we were compared growth data with the different species of the genus Capoeta in Turkey (Table 6). The theoretical 

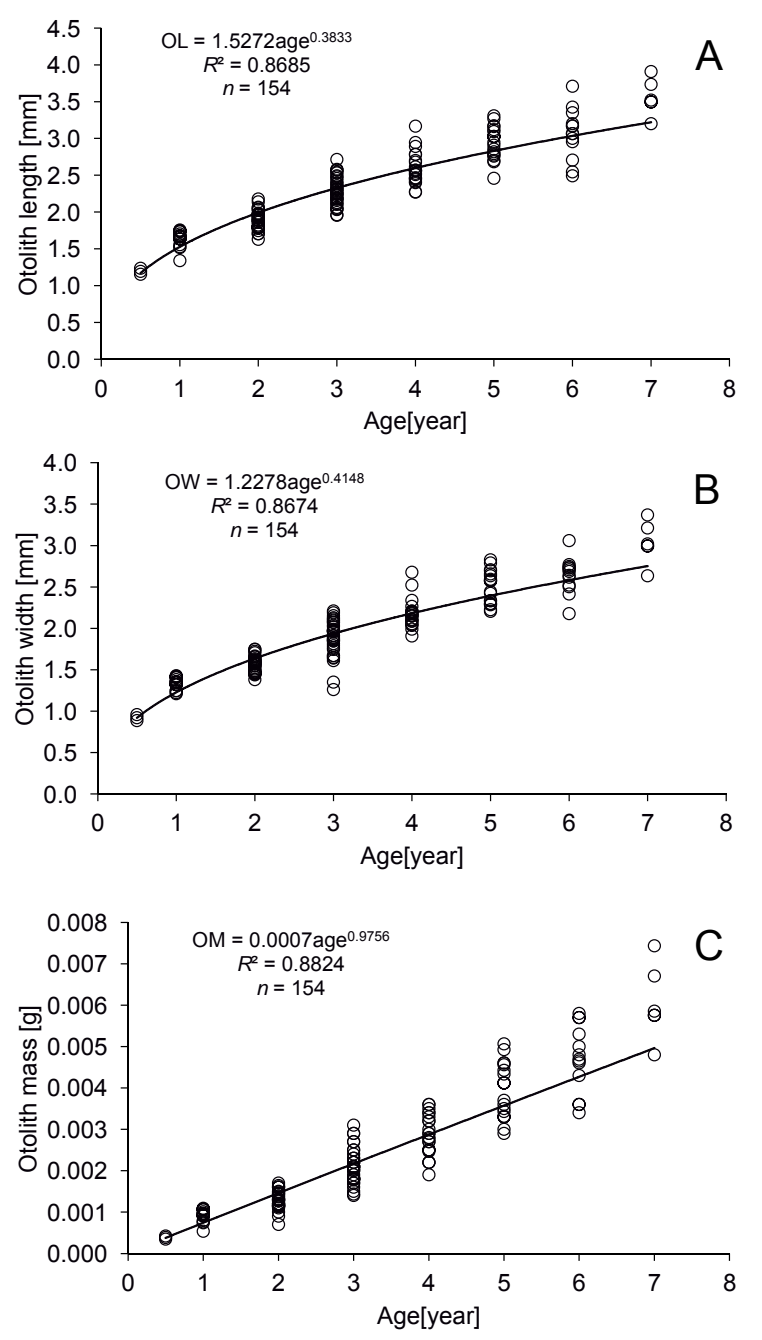

Fig. 5. The relations between otolith morphometrics and age for Capoeta pestai; Otolith length (A), Otolith width (B), Otolith mass (C)

maximal length value obtained by this study were close to the values of estimated by Türkmen et al. (2002) for the C. umbla from the Karasu River, for C. capoeta (Güldenstädt, 1773) (see Elp and Sen 2009) and for C. angorae (Hankó, 1925) from the Ceyhan River (Alp et al. 2005). The growth equation parameters differed from those estimated for $C$. erhani from Menzelet Reservoir (Ayyildiz et al. 2014). Some of the variability between the study results may be due to the specific method of investigation. A more reliable comparison can be reached using standardized investigation method. In this study, $K$ values were close to 0 (zero) that consisted with other studies conducted for different Capoeta species (Türkmen et al. 2002, Alp et al. 2005, Kalkan 2008, Elp and Sen 2009).

Otolith morphometric characteristics (OL, OW and $\mathrm{OM}$ ) examined in this study, were related to the fish length of Capoeta pestai. This result showed that the fish size could be estimated by using the otolith morphometric measurements. The best model for predicting the fish length of $C$. pestai was found for OM. Furthermore, many researchers have shown that otolith morphometric characteristics could be effectively used instead of growth ring counts (Boehlert 1985, Labropoulou and Papaconstantinou 2000, Megalofonou 2006, MatićSkoko et al. 2011, Škeljo et al. 2012). The collection of fish and otolith morphometry is simpler, faster and more economical (Silva et al. 2015). With this perspective, the use of otolith morphometric measurements for age determination of $C$. pestai could provide an acceptable method which is economically acceptable and easy to perform compared to growth ring counts.

In this study, OL, OW, and OM increased with age throughout the life of investigated fish. All models provided accurate estimates, however, OM was the best predictor of fish age for Capoeta pestai. Many authors have emphasized the importance of $\mathrm{OM}$ as age predictor (Labropoulou and Papaconstantinou 2000, Megalofonou 2006, Beyer and Szedlmayer 2010, Zorica et al. 2010, Matić-Skoko et al. 2011). In addition, a recent study by Steward et al. (2009) demonstrated that only otolith weight and otolith thickness continued to increase throughout the life of the fish. The same authors also pointed out those otolith parameters have higher correlations with age than fish size parameters. Also, Boehlert (1985) reported that fish size and the otolith size are correlated, however, otolith size more correlated with fish age than the fish length.

In conclusion otolith morphometric measurements could possibly be used in future as an age predictor for Capoeta pestai. However, this study was limited by the relatively small sample size of some year classes. Therefore, a re-assessment should be done to better estimate the age and growth of C. pestai.

Table 5

Parameters of the linear relations between the observed age and the estimated age from otolith morphometrics of Capoeta pestai collected from Lake Eğirdir during the study period

\begin{tabular}{lccccccccc}
\hline \multicolumn{1}{c}{ Observed age-estimated age relations } & $\mathrm{N}$ & $\mathrm{a}$ & $95 \% \mathrm{Cl}$ of $a$ & $\mathrm{~b}$ & $95 \% \mathrm{Cl}$ of $b$ & $\mathrm{R}^{2}$ \\
\hline Observed age-Age estimated from OL & 154 & 1.324 & 1.201 & 1.452 & -0.942 & -1.278 & -0.573 & 0.821 \\
Observed age-Age estimated from OW & 154 & 1.294 & 1.186 & 1.411 & -0.847 & -1.183 & -0.514 & 0.849 \\
Observed age-Age estimated from OM & 154 & 1.348 & 1.250 & 1.452 & -0.824 & -1.127 & -0.522 & 0.878 \\
\hline
\end{tabular}

$N=$ number of specimens, $a$ = slope of the regression line, $b=y$-intercept, $R^{2}=$ coefficient of determination; OL $=$ otolith length, $\mathrm{OW}=$ otolith width, $\mathrm{OM}=$ otolith mass. 
Von Bertalanffy growth parameters of the different Capoeta species from different regions in Turkey

\begin{tabular}{|c|c|c|c|c|c|c|c|}
\hline Author & Study area & Species & Sex & Age & $L_{\infty}$ & $K$ & $t_{0}$ \\
\hline \multirow[t]{2}{*}{ Türkmen et al. 2002} & \multirow[t]{2}{*}{ Karasu River } & \multirow[t]{2}{*}{ C. c. umbla } & $\mathrm{M}$ & $1-10$ & 42.30 & 0.146 & -0.98 \\
\hline & & & $\mathrm{F}$ & $1-12$ & 45.70 & 0.139 & -0.83 \\
\hline \multirow[t]{3}{*}{ Elp and Sen 2009} & \multirow[t]{3}{*}{ Karasu Stream } & \multirow[t]{3}{*}{ C. capoeta } & M & $1-5$ & 40.49 & 0.177 & -0.90 \\
\hline & & & $\mathrm{F}$ & $1-6$ & 54.65 & 0.130 & -0.72 \\
\hline & & & $\mathrm{M}+\mathrm{F}$ & $1-6$ & 52.58 & 0.145 & -0.72 \\
\hline \multirow[t]{2}{*}{ Alp et al. 2005} & \multirow[t]{2}{*}{ Ceyhan River } & \multirow[t]{2}{*}{ C. angorae } & M & $1-7$ & 47.25 & 0.133 & -0.76 \\
\hline & & & $\mathrm{F}$ & $1-10$ & 62.25 & 0.101 & -0.59 \\
\hline \multirow[t]{2}{*}{ Kalkan 2008} & \multirow[t]{2}{*}{ Karakaya Dam Lake } & \multirow[t]{2}{*}{ C. trutta } & M & $1-7$ & 76.40 & 0.060 & -2.41 \\
\hline & & & $\mathrm{F}$ & $1-10$ & 89.50 & 0.057 & -2.65 \\
\hline \multirow[t]{3}{*}{ Ayyildiz et al. 2014} & \multirow[t]{3}{*}{ Menzelet Reservoir } & \multirow[t]{3}{*}{ C. erhani } & M & $0-6$ & 32.02 & 0.843 & -0.57 \\
\hline & & & $\mathrm{F}$ & $0-6$ & 33.83 & 0.964 & -0.56 \\
\hline & & & $M+F$ & $0-6$ & 33.85 & 0.821 & -0.48 \\
\hline \multirow[t]{3}{*}{ Presently reported study } & \multirow[t]{3}{*}{ Lake Eğirdir } & \multirow[t]{3}{*}{ C. pestai } & $\mathrm{M}$ & $0-6$ & 41.25 & 0.086 & -1.99 \\
\hline & & & $\mathrm{F}$ & $0-7$ & 47.83 & 0.081 & -1.84 \\
\hline & & & $M+F$ & $0-7$ & 52.45 & 0.067 & -1.84 \\
\hline
\end{tabular}

\section{REFERENCES}

Alp A., Kara C., Büyükçapar H.M., Bülbül O. 2005. Age, growth and condition of Capoeta capoeta angorae Hanko 1924 from the upper water systems of the River Ceyhan, Turkey. Turkish Journal of Veterinary and Animal Sciences 29 (3): 665-676.

Ayyildiz H., Emre Y., Ozen O., Yağcı A. 2014. Age and growth of Capoeta erhani (Actinopterygii: Cypriniformes: Cyprinidae) from the Menzelet Reservoir, Turkey. Acta Ichtyologica et Piscatoria 44 (2): 105-110.

DOI: $10.3750 / A I P 2014.44 .2 .03$

Ayyildiz H., Emre Y., Yagci A., Altin A. 2015. Lengthweight relationships of eight freshwater (Cypriniformes) fish species from Turkey. Journal of Applied Ichthyology 31 (5): 963-964.

DOI: $10.1111 /$ jai.12828

Bănărescu P.M. 1999. The freshwater fishes of Europe. Vol. 5. Cyprinidae 2. Part 1. Rhodeus to Capoeta. AulaVerlag, Wiebelsheim.

Beyer S.G., Szedlmayer S.T. 2010. The use of otolith shape analysis for ageing juvenile red snapper, Lutjanus campechanus. Environmental Biology of Fishes 89 (3-4): 333-340.

DOI: $10.1007 / \mathrm{s} 10641-010-9684-\mathrm{z}$

Boehlert G.W. 1985. Using objective criteria and multipleregression models for age-determination in fishes. Fishery Bulletin 83 (2): 103-117.

Calta M., Sen D., Aydin R., Koprucu K., Canpolat O., Coban M.Z. 2010. Age determination technique according to the calcium accumulation in bony structures of Capoeta umbla (Heckel, 1843). Journal of Animal and Veterinary Advances 9 (18): 2357-2364.

Çoban M.Z., Gündüz F., Demirol F., Örnekçi G.N., Karakaya G., Türkgülü I., Alp A. 2013. Population dynamics and stock assessment of Capoeta umbla
(Heckel, 1843) in Lake Hazar, Elazığg, Turkey. Turkish Journal of Veterinary and Animal Sciences 13 (2): 221-231.

DOI: $10.4194 / 1303-2712-v 13204$

Elp M., Sen F. 2009. Biological properties of Capoeta capoeta (Guldenstaedt, 1773) population living in Karasu Stream (Van, Turkey). Journal of Animal and Veterinary Advances 8 (1): 139-142.

Emre Y., Ayyıldız H., Özen Ö., Yağcı A. 2014. Age, growth and otolith morphometry of Capoeta angorae (Cyprinidae) collected from Menzelet Reservoir and Firnız Stream (Turkey). Ege Journal of Fisheries Aquatic Sciences 31 (2): 79-85.

DOI: 10.12714 /egejfas.2014.31.2.04

Erk'akan F., Innal D., Özdemir F. 2013. Length-weight relationships for ten endemic fish species of Anatolia. Journal of Applied Ichthyology 29 (3): 683-684.

DOI: $10.1111 /$ jai.12140

Fey D.P., Linkowski T.B. 2006. Predicting juvenile Baltic cod (Gadus morhua) age from body and otolith size measurements. ICES Journal of Marine Science 63 (6): 1045-1052.

DOI: $10.1016 /$ j.icesjms.2006.03.019

Francis R.I.C.C., Campana S.E. 2004. Inferring age from otolith measurements: A review and a new approach. Canadian Journal of Fisheries and Aquatic Sciences 61 (7): 1269-1284.

DOI: $10.1139 / \mathrm{f04}-063$

Freyhof J. 2014. Capoeta pestai. The IUCN Red List of Threatened Species. Version 2014.1. www.iucnredlist. org (Accessed on 07 July 2014).

Innal D. 2014. Identifying growth parameters for two endemic species Capoeta antalyensis (Battalgil, 1943) and Pseudophoxinus antalyae Bogutskaya, 1992 in Duden Creek, Antalya, Turkey. Journal of Applied Ichthyology 30 (2): 294-299.

DOI: $10.1111 /$ jai.12191 
Javor B., Lo N., Vetter R. 2011. Otolith morphometrics and population structure of Pacific sardine (Sardinops sagax) along the west coast of North America. Fishery Bulletin 109 (4): 402-415.

Kalkan E. 2008. Growth and reproduction properties of Capoeta trutta (Heckel, 1843) in Karakaya Dam Lake. Turkish Journal of Zoology 32 (1): 1-10.

Küçük F., Turna I.I., Demir O. 2007. Capoeta pestai (Pietschmann, 1933) (Pisces: Cyprinidae) 'nin Yayılış Alanı ve Taksonomik Özellikleri. [Taxonomic characteristics and distribution of Capoeta pestai (Pietschmann, 1933) (Pisces: Cyprinidae).] Süleyman Demirel Üniversitesi, Fen Bilimleri Enstitüsü Dergisi 11 (1): 18-25. [In Turkish.]

Labropoulou M., Papaconstantinou C. 2000. Comparison of otolith growth and somatic growth in two macrourid fishes. Fisheries Research 46 (1-3): 177-188.

DOI: $10.1016 / \mathrm{s} 0165-7836(00) 00144-2$

Matić-Skoko S., Ferri J., Škeljo F., Bartulović V., Glavić K., Glamuzina B. 2011. Age, growth and validation of otolith morphometrics as predictors of age in the forkbeard, Phycis phycis (Gadidae). Fisheries Research 112 (1-2): 52-58.

DOI: $10.1016 /$ j.fishres.2011.08.010

Megalofonou P. 2006. Comparison of otolith growth and morphology with somatic growth and age in young-ofthe-year bluefin tuna. Journal of Fish Biology 68 (6): 1867-1878. DOI: $10.1111 / \mathrm{j} .1095-8649.2006 .01078 . \mathrm{x}$

Özcan G., Turan C. 2009. Threatened fishes of the world: Capoeta pestai (Pietschmann, 1933) (Cyprinidae). Environmental Biology of Fishes 84 (4): 359-360. DOI: $10.1007 / \mathrm{s} 10641-008-9426-7$

Sen F., Elp M., Kankaya E. 2008. Growth and reproduction properties of Capoeta capoeta (Guldenstaedt, 1772) in Zernek Dam Lake, Van, Turkey. Journal of Animal and Veterinary Advances 7 (10): 1267-1272.

Silva A.V., Meneses I., Silva A. 2015. Predicting the age of sardine juveniles (Sardina pilchardus) from otolith and fish morphometric characteristics. Scientia Marina 79 (1): $35-42$.

DOI: $10.3989 /$ scimar.04143.16A
Škeljo F., Ferri J., Brčić J., Petrić M., Jardas I. 2012. Age, growth and utility of otolith morphometrics as a predictor of age in the wrasse Coris julis (Labridae) from the eastern Adriatic Sea. Scientia Marina 76 (3): 587-595.

DOI: $10.3989 /$ scimar.03521.07G

Steward C.A., DeMaria K.D., Shenker J.M. 2009. Using otolith morphometrics to quickly and inexpensively predict age in the gray angelfish (Pomacanthus arcuatus). Fisheries Research 99 (2): 123-129.

DOI: 10.1016/j.fishres.2009.05.011

Stransky C., Gudmundsdóttir S., Sigurdsson T., Lemvig S., Nedreaas K., Saborido-Rey F. 2005. Age determination and growth of Atlantic redfish (Sebastes marinus and $S$. mentella): Bias and precision of age readers and otolith preparation methods. ICES Journal of Marine Science 62 (4): 655-670.

DOI: $10.1016 /$ j.icesjms.2005.01.018

Turan C. 2008. Molecular systematics of Capoeta (Cyprinidae) species complex inferred from mitochondrial 16s rDNA sequence data. Acta Zoologica Cracoviensia; Series A: Vertebrata 51 (1-2): 1-14.

DOI: $10.3409 /$ azc.51a 1-2.1-14

Türkmen M., Erdoğan O., Yıldırım A., Akyurt I. 2002. Reproduction tactics, age and growth of Capoeta capoeta umbla Heckel 1843 from the Aşkale Region of the Karasu River, Turkey. Fisheries Research 54 (3): 317-328.

DOI: $10.1016 / \mathrm{s} 0165-7836(01) 00266-1$

von Bertalanffy L. 1938. A quantitative theory of organic growth (inquiries on growth laws II). Human Biology 10: $181-213$.

Zar J.H. 1984. Biostatistical analysis. Prentice-Hall, Englewood Cliffs, NJ, USA.

Zorica B., Sinovčić G., Čikeš Keč V. 2010. Preliminary data on the study of otolith morphology of five pelagic fish species from the Adriatic Sea (Croatia). Acta Adriatica 51 (1): 89-96.

Received: 2 February 2016

Accepted: 21 April 2016

Published electronically: 30 June 2016 